\title{
Костина Д.Д. \\ Мировой опыт государственных мер в области общественных финансов при нивелировании экономических последствий COVID-19
}

Финансовый университет при Правительстве Российской Федераџии (Россия, Москва)

doi: 10.18411/lj-02-2021-102

idsp: ljournal-02-2021-102

Научный руководитель Блохин А.А.

\begin{abstract}
Аннотация
Меры сдерживания COVID-19, введенные правительством России для прекращения распространения вируса, вызвали перебои в работе и привели к потрясениям поставок продаж. Несмотря на эти вызовы, Россия сохраняет значительные макроэкономические резервы для противостояния экономическим проблемам. Рассмотрение опыта нивелирования последствий COVID-19 может помочь России адаптировать и применить меры других стран.

Ключевые слова: пандемия, эпидемия, экономический эффект, розничная отрасль, фармацевтика, Россия, США, Китай, коронавирус.
\end{abstract}

\section{Abstract}

The COVID-19 containment measures imposed by the Russian government to halt the spread of the virus caused operational disruptions and disrupted supply sales. Despite these challenges, Russia retains significant macroeconomic reserves to withstand economic problems. Consideration of the experience of leveling the consequences of COVID-19 can help Russia adapt and apply the measures of other countries.

Key words: pandemic, epidemic, economic impact, retail industry, pharmaceuticals, Russia, USA, China, coronavirus.

Меры сдерживания коронавирусной инфекции, введенные правительством России для прекращения распространения вируса, вызвали перебои в работе и привели к потрясениям поставок продаж. Спад мирового спроса на энергоносители и другие товары, экспортируемые Россией, усиливает негативное влияние на экономику. Больше всего пострадали сектора потребительских услуг. Более того, объем производства в нефтедобывающей отрасли сократится на фоне резкого падения мирового спроса на нефть.

Фирмы страдают от резкого снижения спроса, а со стороны предложения - от неспособности работников выходить на работу и от разрушения глобальных цепочек поставок и транспортных сетей. В результате растет вероятность крупных корпоративных банкротств. Низкие цены на нефть, меры сдерживания и экономический спад приводят бюджет к дефициту. Агентства, проводящие аналитику в области мирового спроса на нефть, ожидают падение ее цены из-за COVID-19. Несмотря на эти вызовы, Россия сохраняет значительные макроэкономические резервы для противостояния экономическим проблемам.

В данной работе будут рассмотрены экономические последствия COVID-19 в России и в мире, обобщен и систематизирован подход разных стран к уменьшению негативных экономических последствий пандемии и подробно рассмотрен опыт Китая как бенчмарк. Актуальность работы заключается в том, что анализ общемирового опыта позволит обобщить, систематизировать и адаптировать меры, предложенные в других странах, под российские условия.

Целью данной работы является анализ экономической ситуации, вызванной вспышкой COVID-19, и формирование практических рекомендаций в отношении мер, 
предпринимаемых правительством. Таким образом, в научном сообществе необходимо посвящать особое внимание изучению экономического эффекта от пандемий и практических решений в области общественных финансов.

Список пострадавших индустрий в России и в мире не ограничивается потребительским и нефтегазовым секторами. Например, падение потребления металлов будет наблюдаться во всех сферах горной металлургии в диапазоне 5-15\%. Также ожидается существенное падение грузооборота из-за значительного снижения промышленного производства в Китае и падения спроса на российское сырье. Падение выручки российских авиакомпаний в 2020 г. может составить свыше 200 млрд. руб. в случае полного прекращения международного сообщения (сокращение выручки на 30 $50 \%)$.

Учитывая, что экономические последствия отражают особенно острые потрясения в конкретных секторах, директивным органам необходимо будет принять целевые меры в области фискальной, денежно-кредитной политики и финансового рынка для оказания помощи домашним хозяйствам и предприятиям.

Домохозяйства и предприятия, пострадавшие от падения спроса, могут быть нацелены на получение денежных переводов, субсидий на заработную плату и налоговых льгот, помогая людям удовлетворять свои потребности, а предприятиям оставаться на плаву.

Например, Италия продлила налоговые сроки для компаний в пострадавших районах и расширила фонд доплаты к заработной плате, чтобы обеспечить поддержку доходов уволенных работников. Корея ввела субсидии на заработную плату для мелких торговцев и увеличила пособия неработающим и ищущим работу.

В период вспышки эпидемии экономическая политика Китая была в основном направлена на поддержку связанных с вирусом секторов производства и розничной торговли, в том числе с помощью инструментов фискального, денежного и социального страхования. Эти меры в первую очередь состояли из:

- Налогово-бюджетная политика, включая налоговые вычеты и субсидии.

Центральное правительство выпустило стимулирующий пакет для расширения мощностей по производству товаров и услуг, связанных с борьбой с вирусом. Центральное правительство предоставляло субсидии в виде кредитных платежей производителям продукции, связанной с борьбой против вируса, и стартапам, которые серьезно пострадали.

- Денежно-кредитная политика, включая смягчение условий кредитования, снижение кредитных ставок и пролонгацию долга.

Народный Банк Китая облегчил рыночное кредитование с помощью традиционных инструментов политики, включая операции на открытом рынке, нормативы резервных требований, кредитные механизмы, политику рефинансирования и повторного учета. Центральный банк также потребовал от коммерческих банков улучшить качество услуг, включая создание «зеленого канала» для бизнеса, связанного c COVID - 19, а также увеличение объема электронных платежей и онлайн-услуг.

- Полисы социального страхования, включая отсрочку или удержание страховых выплат.

Местные органы власти проводили политику, направленную на стабилизацию занятости и оказание помощи МСП в преодолении угроз во время эпидемии. Когда эпидемия в Китае начала утихать, правительство сосредоточилось на восстановлении экономики. Центральное правительство требовало, чтобы местные органы власти упростили процедуру согласования бизнеса и оптимизировали услуги, чтобы побудить предприятия и работников возобновить работу и производство.

- Возобновление работы фондового рынка. 
Центральное правительство в кратчайшие сроки вновь открыло фондовый рынок.

- Налогово-бюджетная политика, включая снижение налогов, освобождение от пошлин, сокращение расходов и субсидии.

НДС для малого бизнеса был освобожден; некоторые взносы на социальное страхование работников были освобождены или уменьшены вдвое; а местным органам власти было предложено отказаться от городских налогов на землепользование, чтобы побудить землевладельцев снизить или отказаться от арендной платы.

- Денежно-кредитная и финансовая политика.

Финансовые учреждения осуществили ряд мер финансовой поддержки, особенно для МСП, включая снижение процентных ставок, увеличение пролонгации задолженности и возобновление кредитов, а также предоставление конкретных кредитных линий для возобновления производства.

- Отраслевая политика, ориентированная на крупные инфраструктурные инвестиционные проекты и цепочки поставок.

Несколько министерств координировали усилия по эффективному расширению внутреннего спроса путем стимулирования инвестиций в инфраструктуру. Центральное правительство стремится укреплять международную координацию и сотрудничество и предоставлять больше кредитов основным компаниям в соответствующих отраслях для поддержания международных и внутренних цепочек поставок.

- Торговая политика, направленная на стабилизацию внешней торговли и инвестиций.

Центральное правительство приступило к осуществлению комплекса мер по стабилизации международной торговли и иностранных инвестиций и продолжает расширять рынок. Коммерческим страховым компаниям было предложено предлагать краткосрочное страхование торговых кредитов и более низкие сборы для торговых фирм.

В качестве заключения хотелось бы отметить актуальность и необходимость изучения данной тематики и подчеркнуть, что потенциальным направлением изучения изложенного вопроса является построение моделей применение различных предложенных мер в России.

$$
* * *
$$

1. Барабанов O.H. Первый год COVID-19: социально-политические последствия пандемии глазами экспертов Клуба «Валдай» // Международный дискуссионный клуб «Валдай» - 2021. URL: https://ru.valdaiclub.com/a/reports/pervyi-god-covid-19/ (дата обращения 30 января 2021 года).

2. Гурков А. Коронавирус: ЕС чрезмерно зависит от лекарств из Китая // DW - 2020. URL: https://www.dw.com/ru/коронавирус-ес-чрезмерно-зависит-от-лекарств-из-китая/a-52761829 (дата обращения 24 января 2021 года).

3. Adda, J. Economic activity and the spread of viral diseases: Evidence from high frequency data // The Quarterly Journal of Economics - 2016. P. 891-941.

4. Gaspar, V and P Mauro. Fiscal Policies to Protect People During the Coronavirus Outbreak // IMF Blog 2020. URL: https://blogs.imf.org/2020/03/05/fiscal-policies-to-protect-people-during-the-coronavirusoutbreak/ (дата обращения 13 января 2021 года).

5. Georgieva K. Potential Impact of the Coronavirus Epidemic: What We Know and What We Can Do // IMFBlog - 2020. URL: https://blogs.imf.org/2020/03/04/potential-impact-of-the-coronavirus-epidemicwhat-we-know-and-what-we-can-do/ (дата обращения 13 января 2021 года).

6. Gopinath G. Limiting the economic fallout of the coronavirus with large targeted policies // Mitigating the COVID Economic Crisis - 2020. P. 41-47.

7. Huang C., Wang, Y. and Li, X. Clinical Features of Patients Infected with 2019 Novel Coronavirus in Wuhan, China // The Lancet - 2020. P. 497-506.

8. Huang Y., Lin C., Wang P. and Xu Z. Saving China from the coronavirus and economic meltdown: Experiences and lessons // Mitigating the COVID Economic Crisis - 2020. P. 77-91. 